\title{
At the Mid of Polarity: Rethinking Medium Farms as Solution to Vulnerability for Small-scale Farmers in Sub- Saharan Africa
}

\subsection{3/alanyaakademik.327771}

\section{Edward Simon MGAYA}

Assistant Lecturer. Mkwawa University College of Education, Department of History, Political Science and Development Studies, P.O. Box 2513, Iringa-Tanzania. edwardmgaya@yahoo.co.uk; emgaya@muce.ac.tz Mobile: +255767 208750

Keywords:

Agriculture

Food

Medium-scale farm

Farming

Africa

Received: 11.07.2017

Accepted: 01.11.2017

\begin{abstract}
Strategies to increase agricultural productivity in Sub-Saharan Africa have mostly been thought to occur through one of the two predominant pathways: large-scale commercial production or intensification of small holder plots. Considerable efforts have been made to further each of these two strategies. It is clear, therefore, that the efforts to go beyond such polarized academic debate on the key challenges to farm size in relation to food productivity is still wanting. Such polarization of the debate presents the obvious problem of limiting solutions by obscuring those that fall in the middle. It is in such a context that the argument for the expansion of medium-scale farming is lost. This article brings alive the lost in the debate about the expansion of medium scale farmers. Arguing from transitional model, the article reimagine medium farms as solution to vulnerability of small scale farmers and their food productivity.
\end{abstract}

\section{THE CONTEXT}

Food security and food sovereignty are increasingly of global importance with concerns not limited just to the developing world. Although the World Resources Institute (2011) records have revealed sustainable and consistent increases in per capita food production over the last several decades, the reality of it, seems less in the geographically part of African continent that lies south of Sahara. The Sub-Sahara Africa (SSA) consists of all African countries that are fully or partially located south of the Sahara. SSA comprises of West, East, central and southern African countries. It contrasts with North Africa whose territories are part of the League of Arab states within the Arab world. Somalia, Djibouti, Comoros and Mauritania are geographically part of sub-Saharan Africa despite their being Arab states and part of Arab world (Barakat, 1993: 80).

Despite the presence of comparatively large arable land in developing countries, agriculture has not yet genuinely assured deliverance from food insecurity. For instance, SSA has been 
experiencing different periods of food shortages mainly because of insufficient food production despite of its having a relatively undisputable potential for food production. External urge for realization of food security in SSA does not promise genuine relief. For instance, the European Union Community (EUC) has sought the improvement of food security for the least-developed countries while also engaging in massive export-based land acquisitions in those same regions (Graham, et. al. 2011:3). This kind of paradox is experienced in varying degrees to various developing countries.

African agriculture is dominated by small-scale farmers predominantly worked by women (GCGH, 2013:1). Small-scale farmers are the most vulnerable, as they are confronted with several challenges that include, but are not limited to, inadequate access to improved agricultural inputs, limited access to output markets, and the vagaries of climate change. They also have limited access to improved agricultural technologies and innovations and are highly susceptible, and less resilient to frequent crises and shocks. These small-scale farmers generally operate in complex agricultural production systems characterized by very low levels of productivity. In the past decades huge efforts have been made to increase the productivity of this peasant model. Despite these efforts, the majority of youth still leave their land to move to urban centres, as there is no serious business case in the continuation of production on small plots of land. The distribution of farm sizes in Sub-Saharan African countries shows the majority of farms are of less than two hectares (ha) of land, (Conway, 2011:2; Lowder et. al. 2014: 13). About 60 percent of those farms are smaller than one hectare and control close to 20 percent of farmland while few farms reach larger than fifty hectares and comprise only a small share (Lowder et. al. 2014: 13).

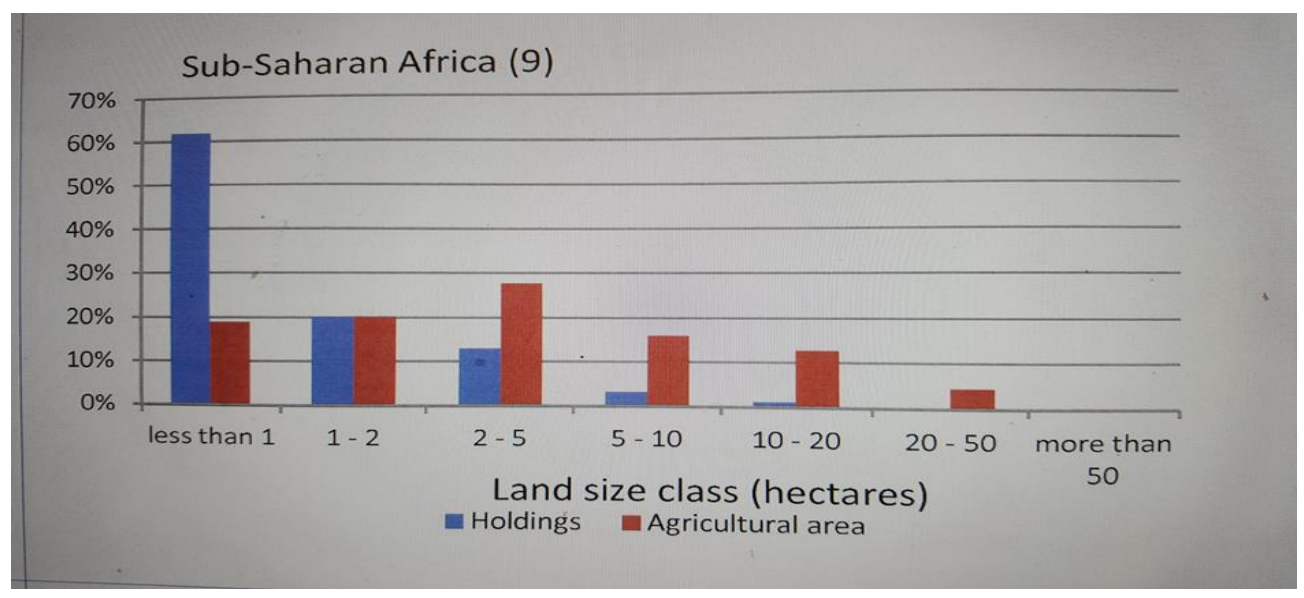

Figure1: Average distribution of farm and farmland area by size

Source: Imaged from Lowder et. al. (2014: 14)

The main notional object of the official policy narratives on poverty reduction and food security, agricultural production in most of these countries is still very low. Numerous explanations for the lack of agricultural transformation have been proposed. For instance, Hyden (1984:107-9) clearly describes that the post-independence Tanzania's, policy making, developed four main features which have made agricultural transformation an unrealized dream. First is a 'strong urge to do everything and do it at once.' Policies have become 'frontal attacks', 'operations' and 'matters of life or death.' Second, 'policy makers often decide on matters without first having obtained full and detailed knowledge of the possible 
consequences of their decisions.' Third, policy makers have been unwilling 'to use the past as a source of guidance for the future.' Last, public sector officials work in a context where public expectations constantly exceed what can be attained. The devastating impacts of these highlighted set of explanations for lack of agricultural sustainability and food security, are nevertheless being underestimated. The result of it has been blaming peasant agriculture as the main source of insufficient food production in Africa.

Like many proponents of the neo-liberal paradigm, the World Bank is particularly unmoved by cultivation on small plots and a general subsistence orientation of the peasantry (WB, 2008:91). It, therefore, advocates for the realization of economies of scale. Invariably, these trajectories infer extensive displacement of small-scale farmers given their historically disadvantaged capital assets. Despite their avowed poverty concerns, African government officials and development agencies alike, tacitly tend to accept small-scale displacement as necessary for agricultural modernization. This being the case, small-scale farmers have become vulnerable even at the hands of their own governments, which are sceptical of the potentiality of small-scale farmers in the greater scheme of sustainable food production, hence advocating for large-scale commercial agriculture. As a result, a call for depeasantization in favour of commercial large-scale farming is growing in SSA.

The policies that serve to consolidate large-scale agriculture at the expense of small-scale agriculture have led to massive land grabbing in SSA. One of the recent examples on such trend in Africa is well documented and analysed by Schoneveld (2014:35-50) who documents a total of 563 acquisitions comprising of 22.7 million hectares in Africa since 2005. However, Sitko, and Chamberline (2015:870) considers such estimates to be conservative as has excluded acquisitions smaller than 2,000 hectares. Although empirical investigation into the implication of land grabbing on food security are still infant, such land acquisitions have raised great concerns about their current and future effects on land availability for small-scale agriculture. It has a heavy costs on food security, nationally and globally. This is because, firstly, the large investors taking land that is suitable for food production may not necessarily produce food crops. Tanzania, for instance, has witnessed a scramble for large tracts of land for bio-fuel production (Madoffe, et. al 2009; Kamata, 2009:1-2). The nation's capacity to produce enough food is thus affected by land used for production of crops for biofuel. In the long run this will worsen the food shortage leading to escalating food prices. Second, experts are increasingly concerned with the disease hazards of large-scale intensive factory farming as exemplified by the avian influenza virus and its link to intensively farmed poultry. It has been observed that while factory production of animals is often associated with the source of such viruses, it is the large-scale farms' proximity to small-scale producers, lacking sufficient bio-safety measures, which fans the spread of such disease. In the longer term, the incidence of disease in intensive farming could be compounded by the temperature changes and unpredictable and erratic weather associated with global warming. Third, given the uncertain course of global warming on Africa's weather patterns, intensive large-scale farming is an especially high-risk form of agriculture that concentrates reliance on a restricted number of plant and animal species. The crop biodiversity offered by extensive small-scale farming is likely to be at much lower risk for ensuring a continuous supply of food for the global population. Large scale farming therefore, inevitably increases hunger in developing countries as it displaces subsistence farming families, who are meeting at least most of their basic food needs, and fails to provide them with economic opportunities to purchase foods they are no longer able to produce for themselves. Therefore, if the urge for large-scale farming is taken without considering the context under which it operates, it might inevitably increase hunger in developing countries. 
From the foregoing debate on food security in SSA, it is evident that, academic and media have grown their attention on food production with the focus of their discussion being on two divergent areas. The first one involving a substantial reinvigoration increase in donor domestic government to increase food productivity on small scale farms. The second strategy being the rapidly increasing global investments in African land for large scale-scale food production (Deininger and Byerlee 2011). However, neither of the two strategies have evidently and by itself shown great success in relieving SSA from food insecurity. Considering the diversity and complexity of the problem of food security, therefore, other possible solutions must be sought. This is in light of the fact that for a country that is largely agrarian, achieving food self-sufficiency should begin with the peasants. Hastily opting for commercial large scale farming in a context where people are not assured of their basic needs jeopardizes the goal to have food security. It would rather fit in the context in which commerce is at the top of agenda. By now SSA ought not to be the one. This paper suggests middle sized farms where farmers may use technology to create efficient and mechanized farming, but without creating large-scale mega-farms as promoted by large Trans National Cooperation.

\section{CALL for MEDIUM-SCALE FARMING}

In a better-late-than-never attempt to revive the African agricultural advances, donors are now re-thinking ways of boosting small-scale agriculture (Dorword, 2009:6). However, all efforts are needed at present and they should be seen as complementary rather than competing with one another. African farmers who have been deprived of research, extension, and marketing support for decades are eager to increase their yields and sustainability. They are in a position to experiment with what works for them.

Every era has its challenges demanding specific responses. In SSA, small-scale farmers need a way forward that has the same novelty of the Asian green revolution, but which responds to specifically African needs. Largely unrecognized in the stylized debate over commercial versus small-scale are medium-scale farms and their potentiality to overcome the vulnerability of traditional small-scale farms. Medium-scale farms are generally defined as owning and controlling between 5 and 100 ha of land (Sitko and Chamberlaine, 2015:870). They are differentiated from small-scale farmers, who are the majority (more than $70 \%$ ), and control less than 2 ha of land (Thurow, 2010). As a way of minimizing small-scale farmers' vulnerability, a transition to medium-scale farming should be encouraged. This entails stimulating a business model in which those who want to farm are not just surviving, but have the option to earn a decent living comparable to (other) jobs in the cities. By any means this demands encouraging a specific farm size (medium) and farming models that support farmers who want to grow, expand, and innovate in and towards those levels. In fact, supportive projects that are directed to sustainable production systems should focus on this. We should calculate how much land is needed for a decent income, and focus efforts on getting to these sizes. There can indeed be an economy of scale, especially once farm size grows, but within the threshold that can be managed by single or combined households.

With insight from Ghana, Chapoto et al. (2013: 15) revealed that home-grown medium scale farmers have had at least twice the maize yields of small holder farmers. In Tanzania, there are cases where farm households are found to be expanding their cultivated areas (Binswanger and Gautam, 2010). It is also documented in the case of Zambia, where emerging medium scale farmers have transitioned to cultivate anywhere from about 12 to 50 acres of land (Sitko and Jayne, 2012:2). Although sometimes using income and resources from non-farm employment, medium farmers in these areas have expanded their agricultural 
productivity (Sitko and Jayne, 2012:5). This suggests that medium-sized farms might constitute a viable alternative to vulnerable small-scale farming. It is thus imperative to consider agricultural land expansion as it relates to agricultural productivity at the micro economic level.

\section{INSIGHTS from GHANA}

The suggestion for medium-scale farming does not mean reducing support to small-scale farmers. It only means that we have to think in transition models to get there. There are already some countries where this has worked. For instance, in Ghana, among the medium and large-scale farmers, $78.5 \%$ of the farmers started as small-scale farmers, starting with less than five ha, whereas $9.3 \%$ of these medium-scale farmers started with farms less than 0.5 ha (Chapoto, et al. 2014:9). This small-farmer-led transition in Ghana is also affirmed by a survey conducted by the International Food Policy Research Institute (IFPRI) and Savannah Agricultural Research Institute (SARI), which revealed that a pattern of indigenous transition in Ghana is occurring from small-scale to mostly medium-scale farming (IFPRI/SARI, 2013). Although the rapid growth of medium-scale farmers is also evident elsewhere in Zambia and Kenya, contrary to that of Ghana, such growth is driven by the urban elite with little evidence of growth through capital accumulation and expansion from smallholder farming. Studies reveal that an internally transformed class of medium-scale farmers has been able to grow under numerous challenges affecting the agricultural sector. Medium-scale farmers have, therefore, displayed more resilience to agricultural challenges compared to small-scale producers. In this way, medium-scale farming has provided greater optimism about the prospects for a successful smallholder-led farm expansion under favourable conditions.

It is important to note that such a transition occurred under a certain enabling policy environment. For that matter, the government and some other development agencies began by designing home-grown medium to large-scale farmers' development programs considering them as nucleus change agents to help create a more vibrant and commercialized smallholder sector (Chapoto et al. 2014:1). The implementation of a block farm program as well as procurement and sale of machinery at subsidized prices to medium- and large-scale farmers has been one of such efforts. Also important to note is the use of value chain approach to help link smallholder farmers to markets, finance, inputs, equipment services, and information through relatively larger nuclei (medium-scale) farmers and aggregators who have the capacity to invest in the value chain.

\section{LESSON LEARNED and POLICY ISSUES for FARMER-LED TRANSFORMATION}

It has been proven that it is possible to grow small-scale farmers into medium or larger-scale farmers in a transitional model. The model suggested is essentially based on the premise that symbiotic relationships exist between the small-scale farmers and medium to large-scale farmers. There are, therefore, positive spill over effects from developing or channelling assistance to such medium farmers. The lesson learned in Ghana reveals that small-scale farmers can benefit from the existence of medium and large-scale farmers present in their communities. These farmers have a potentiality of being used by development programs to spread benefits to reach small farmers. That being the case, therefore, there is a need to recast the debate on agricultural transformation through large- or small-scale farming ranges and put attention also to special groups of smallholder farmers that have and continue to transition to become medium-scale farmers. Such consideration will assist in leveraging the interactions between smallholder and medium- to large-scale farmers so as to transform the agricultural 
sector in SSA. Chapoto et al (2013:15) reveals that, in Ghana, roughly half of the land are cultivated under the control of medium-scale farmers. These farmers contribute substantially to food production in the country. Although the overall impact of medium-scale farms may necessarily differ by country, the fact remains that the more assistance provided to nucleus farmers, the more impact on productivity it will have.

The smallholder transformation and growth of medium-scale farming will obviously require a desirable policy environment. It will, therefore, be a reflection of the particular type of policies and investment in the agricultural sector. For other SSA countries to have the transformation positively realized, several policies must be put into place. It is through intensifying inputs, provision of subsidies, improved technology, and good management that small-scale farmers will grow into medium- and even large-scale stages. Allowing foreigners alone to indulge in large-scale commercial farming activities will neither resolve rising unemployment, nor improve food security. There should also be investment in rural infrastructure and incentives to discourage rural urban migration by making farming pay comparable to other jobs in cities. Governments should, therefore, encourage farmers in their efforts to cultivate larger extents to resolve unemployment in rural areas and strengthen and improve countries' food security.

In the efforts to promote medium-scale farming, one needs to also think of models through which medium-sized farms can be created. On average, it is expected that medium-scale farmers will require much more land compared to the small-scale farmers. A recent study in farm structure in Ghana, Kenya, and Zambia indicates that, despite the international media's focus on land grabs by foreign investors the land controlled by medium-scale farmers now exceeds that of foreign and domestic large-scale farm holdings combined (Jayne et. al., 2014: 37). In most African countries there is a relatively inverse correlation between land holding size and the proportion of land holding under cultivation. Although the region's underutilized land resources are concentrated in relatively few countries, it still gives room for smallholder expansion through various land acquisition models, such as buying or inheriting such land. There can also be cooperatives of small-scale landowners, that farm in a medium-scale joint farming model. Different models are possible and should be tested to fit in different cultures and contexts. Most important for us is to think beyond the dualist small-scale farm versus large-scale commercial farm. We can learn from what happened elsewhere. Between the 1970s and 1980s, farms were very small in the Netherlands. Successors were not able to earn a competitive income out of farming. So the European Union set quotas for each producer. In the end, the farmers who wanted to quit leased out their quota to those who wanted to grow. This policy restructured the farming model in the Netherlands. Of course, each time and place requires different solutions, but we can use parts of models and thinking of previous experiences in new settings as SSA.

The urge for an increase in the number of medium scale farmers in SSA may reflect a process of land consolidation associated with economic transformation (Deininger and Bryerlee, 2011:87). While such targeting of medium farmers can be considered as an explicit attempt to ensure increased food production, there should be measures to ensure that such land consolidation becomes an agriculturally led one. If properly handled, such consolidation of agricultural land by medium-scale farmers may be read as a positive transformation. It will be one which is consistent with the stylized narrative of small-scale, farmer-led processes of land accumulation and consolidation resulting from economic structural transformation (Mellor, 1976). Such a move will basically tally with the analysis coming out of the green revolution experience in Asia. Its literature on economic structural transformation outlines a fairly linear 
process by which agricultural productivity growth on small-scale farms potentially transforms agrarian economies into more industrial ones. The process will be advantageous in that:

- The course of action will have started with agricultural productivity growth among the rural majority of small-scale producers.

- The small-scale productive farmers with sufficient land to produce surplus will lead the process.

- The money they mobilize from surplus production will stimulate demand for goods, services, and jobs in various off-farm sectors of the economy. Over time, consolidation of farmland occurs as more efficient producers rent or buy land from their less efficient neighbours.

- With significant subsidy support and access to wage income, medium-scale farmers are in a better position than most small-scale farmers to intensify production of low cost cereals through the acquisition of capital intensive inputs and the achievement of greater economies of scale in production and marketing.

Nevertheless, while thinking of promoting medium scale farms in SSA, it is also important to note that there are areas of concern for its good performance. For instance, the growth in medium-scale farmers has a spatial relationship with land ownership inequality. What can be done from a policy perspective to retain viable land access opportunities for existing smallscale farmers without stifling the potential of domestic medium-scale investment in agriculture? An important place to begin is to provide a clear framework for protecting the land rights of current small-scale farmers, particularly by encouraging co-operatives of smallscale landowners that farm in a medium-scale joint farming model.

\section{CONCLUSION}

To be able to address food shortage in SSA, there is a need to recognize the diversity and complexity of the problem of food security as experienced by the food insecure groups themselves. This is in light of the fact that for a country that is largely agrarian, achieving food self-sufficiency should begin with the peasants. Opting for commercial large scale farming in a context where people are not assured of their basic needs jeopardizes the goal to have food security. Thus, this paper suggests middle sized farms where farmers may use technology to create efficient and mechanized farming, but without creating large-scale mega-farms as promoted by large Trans National Cooperation.

Thinking about the role of African small-scale farms has evolved over time, and this role is increasingly being seen in a broader economic context. The discussion about small-scale farms should be expanded beyond a strict focus on small versus large farms to reflect the idea that optimal farm size is a dynamic concept that changes as a country's overall economy grows and as non-agricultural sectors develop. Within this framework, interventions must be tailored to the different types of small-scale farms and the specific contexts in which they operate. Therefore, the appropriate livelihood strategies should not be treated as a single and unique pathway but instead as a dynamic process that reflects the different types of smallholders and economies. Considering the vulnerability of small-scale farmers in subSaharan Africa, this article has argued for need to experiment with co-operatives of smallscale landowners, that farm in a medium-scale joint farming model. This is with conviction that, with significant subsidiary support, medium scale farmers have a potentiality of being at a better position than most small-scale farmers. They are better-off in terms of intensifying production of low cost cereals through the acquisition of capital intensive inputs and the 
achievement of greater economies of scale in production and marketing. This suggests a transformative model in which a quick jump to overemphasizing on large-scale commercial farming is retarded.

\section{REFERENCES}

BARAKAT, H. (1993), The Arab World: Society, Culture, and State. University of California Press, California.

BINSWANGER-Mkhize, H. P., GAUTAM, H.P. (2010), Towards an Internationally Competitive Tanzanian Agriculture. Washington, DC: Mimeo.

CHAPOTO, A. et. al. (2013), “Agricultural Commercialization, Land expansion and Home-grown large scale Farmers: Insights from Ghana”. IFPRI Discussion paper01286. [Online] http://ssrn.com/abstract=2343154, retrieved on 12 may 2016.

CHAPOTO, A., HAUSSOU, N., MABISO, A. and COSAR, F. (2014),"Medium and Large-scale Farmers and Agricultural Mechanization in Ghana: Survey Results", International Food Policy Research Institute (IFPRI), Washington, D.C. http://orcid.org/00000002-9198-3342

CONWAY, G. (2011), On Being a Smallholder. Rep. International Fund for Agricultural Development. [Online], www.ifad.org/events/agriculture/doc/papers/conway.pdf. Retrieved on 14 June 2016.

DEININGER, K.W., BRYERLEE, D. (2011). Rising Global Interest in Farmland: Can it Yield Sustainable and Equitable Benefits? World Bank Publications, Washington DC.

DORWORD, A. (2009), Rethinking Agricultural Input Subsidy Programmes in a Changing World, Food and Agriculture Organisation (London: School of Oriental and African Studies, April.

GCGH (Grand Challenges in Global Health), (2013), "Labour Saving Strategies Innovations for Women Smallholder Farmers." https://gcgh.grandchallenges.org/challenge/laborsaving-strategies-and innovationswomen-smallholder-farmersround-11, retrieved on $25 \quad$ June 2016.

GRAHAM, A., AUBRY, S., KUNNEMANN, R., SUAREZ, S. (2011). The Role of the EU in Land Grabbing in Africa - CSO Monitoring 2009-2010 "Advancing African Agriculture" (AAA): The Impact of Europe's Policies and Practices on African Agriculture and Food Security. International Conference on Global Land Grabbing, 6-8 April 2011 University of Sussex, UK.

HYDEN, G. (1984), 'Administration and Public Policy', in Barkan, Joel (ed) Politics and Public Policy in Kenya and Tanzania, New York: Praeger, $\quad$ pp 103-124. 
IFPRI/SARI (2013), International Food Policy Research Institute \& Savannah Agricultural Research Institute, Survey Data on Medium and Large-Scale Farmers and Agricultural Mechanization, Accra, Ghana.

JAYNE, T., CHAPOTO, C., SITKO, N., CHAMBERLIN, J. (2014), "Is the Scramble for Land in Africa Foreclosing a Small-holder Agricultural Expansion Strategy?" International Affairs. Spring issue, pp. 35-53.

KAMATA, N. (2009), "Imperial Projects and Food Crisis in the Periphery", Pambazuka News. http://www.pambazuka.org/en/category/features/56412, retrieved on 12 October 2016.

LOWDER, S.K., Skoet, J. and Singh, S. 2014. 'What do we really know about the number and distribution of farms and family farms worldwide?' Background paper for The State of Food and Agriculture April 2014. ESA Working Paper No. 14-02. Rome, FAO.

MADOFFE, S., MALIONDO, S., MAGANGA, F., MTALO, E., MIDTGAARD, F., BRYCESON, I. (2009) "Biofuels and Neo-colonialism", Chemichemi, Issue No. 1 April. Pp. 22-25.

MELLOR, J.W. (1976), New Economics of Growth: A Strategy for India and the Developing World, A Twentieth Century Fund Study. Cornel University press: Ithaca, New York.

SCHONEVELD, G. (2014), 'The Sectorial and Geographic Patterns of Large scale Farmland Investments in Sub-Saharan Africa.' Food Policy, 48. 3450. DOI:10.1016/j.foodpol.2014.03.007.

SITKO, J. N., JAYNE, T. (2012), "The Rising Class of Emergent Farmers: An Effective Model for Achieving Agricultural Growth and Poverty Reduction in Africa?" Indaba Agricultural Policy Research Institute Working Paper 69. Lusaka.

SITKO, N., CHAMBERLAINE, J. (2015), the Anatomy of Medium-scale Farm Growth in Zambia: What are the Implications for the Future of Smallholder Agriculture? Land, 4, (2015) 869-887 [online] Www.mdpi.com/journal/land, retrieved on 12 July 2016.

THUROW, R. (2010), “the Fertile Continent: Africa, Agriculture's Final Frontier". Foreign Affairs, 102-110.

WORLD BANK (2008) World Development Report 2008: Agriculture for Development, Washington D.C: The World Bank Group.

WORLD RESOURCES INSTITUTE. 2011. Agricultural Production Indices: Food production per capita index. [Online]. Available at: http://earthtrends.wri.org/ , retrieved on 26 May 2016. 